ISSN 2078-6441. Вісник Львівського університету. Серія географічна. 2013. Випуск 44. С. 235-243. Visnyk of the Lviv University. Series Geography. 2013. Issue 44. P. 235-243.

$631.482(282.247 .2)$

\author{
рій конечний \\ ввівський н ціон льний університет імені в н \\ вул. . орошенк , 41, 79000, м. ввів, кр їн
}

х р ктеризов но фр кційно-груповий скл д гумусу люві льних дернових, лучних, лучноболотних і болотних грунтів 3 пл ви р. хідний уг. ро н лізов но результ ти досліджень якісного скл ду гумусу грунтів з пл в рік вітчизняних і з рубіжних дослідників. озглянуто основні пок зники фр кційно-групового скл ду гумусу досліджув них грунтів.

лючові слов : люві льні грунти, гумус грунту, фр кційно-груповий скл д гумусу, гумінові кислоти, фульвокислоти.

рунтотворний процес тісно пов'яз ний з н копиченням і колообігом орг нічних речовин, які є джерелом елементів живлення для рослин, що вивільняються в процесі мінер ліз ції гумусу. умусові речовини інтенсивно вплив ють н структуроутворення, фізичні й фізико-хімічні вл стивості грунтів. ок зники якісного скл ду гумусу використовують для ді гностики т визн чення генезису грунтів [7].

кість гумусу оцінюють з пок зник ми ступеня гуміфік ції, результ т ми фр кційного т групового скл ду, т кож з природою гумінових кислот. руповий скл д гумусу х р ктеризує вміст гумінових кислот, фульвокислот і гумінів. р кційний скл д гумусу є функцією кислотності грунтів, ступеня мінер ліз ції грунтового розчину т мінер логічного скл ду мулистої фр кції грунтів [8, с. 45].

процесі дослідження фр кційно-групового скл ду гумусу люві льних грунтів з пл ви р. хідний уг використ но метод юрін в модифік ції оном рьової т лотнікової.

кісний скл д гумусу люві льних грунтів вивч ли вітчизняні т 3 рубіжні н уковці [1-6; 10-12].

скл ді гумусових речовин н мулу в з пл в х рік к рп тської низовини домінує груп гуміну, н яку прип д є 35,0-38,3 \% від з г льного вмісту орг нічної речовини. исокий відсоток цієї групи гумусових речовин пов'яз ний з міцністю її зв'язків із мінер льною ч стиною н мулу. міст гумінових т фульвокислот дешо нижчий через вищу їхню мігр ційну зд тність. ількість гумінових кислот сл бко змінюється в різних ч стин х з пл ви і ст новить 33,3-36,5\% від з г льного вмісту орг нічної речовини. руп фульвокислот н йбільш легкорозчинн у воді, тому іiі вміст н йнижчий з усіх гумусових речовин $(26,5-31,7 \%)$ [1].

к 3 зн ч є . обровольський, гумус люві льних дернових грунтів 3 пл в рік центр льної ч стини уської рівнини відрізняється від гумусу люві льних лучних грунтів меншим ступенем гідролізов ності т рухомості, дещо вищим відношенням гумінових кислот до фульвокислот. і відмінні озн ки, н думку вченого, цілком можн пояснити менш гідроморфним режимом дернових грунтів порівняно з лучними [5].

(C) конечний ., 2013 
. орін з'ясув в, що в скл ді гумусу люві льних грунтів ісостепу кр їни (н прикл ді p. іверський онець) перев ж ють гумінові кислоти. е підтверджене співвідношенням гк: фк, яке в більшості про н лізов них зр зків грунту ст новить не <2, в окремих вип дк х сяг є 8,58. ум тний тип гумусу в 3 пл вних грунт х 3 пок зник ми чітко відрізняється від зон льних чорноземних грунтів 3 т ким же його типом - тут гумінові кислоти утворені перев жно під впливом $\mathrm{R}_{2}{ }_{3} \mathrm{i}$, менше, (особливо в оглеєних горизонт х) [3].

ослідженнями . блонських визн чено, що люві льні в жкосуглинкові грунти центр льної ч стини з пл ви формуються в оптим льних умов х для гумусон копичення й утворення гумусу гум тного типу. гумусовому горизонті співвідношення гк: фк ст новить 1,7-2,5, і гумус х р ктеризують як гум тний з дуже низьким вмістом “вільних”, високим - зв'яз них з к льцієм і глинистими мінер л ми гумінових кислот, т кож середнім вмістом нерозчинного з лишку (40-45\%). і зрост нням гідроморфізму в люві льних лучно-болотних грунт х погіршуються умови гуміфік ції орг нічних з лишків, зменшується співвідношення гк: фк до 1,5-1,7 у гумусовому горизонті і 0,4-0,1 у глейових горизонт х [12].

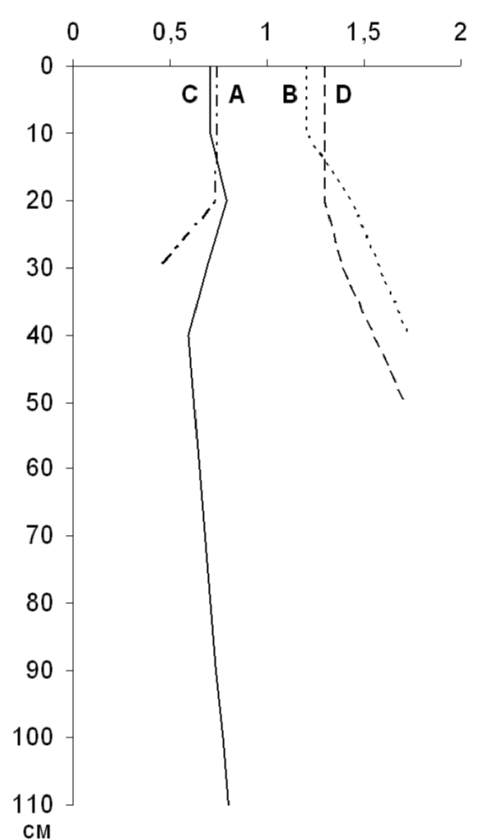

ис. 1. ип гумусу ( гк: фк) у профілях люві льних грунтів з пл ви р. хідний уг:

- дерновий короткопрофільний (розріз 2- );

- лучний (розріз 4- ); - лучно-болотний (розріз 3- ); D- болотний (розріз 5- ). ля фр кційно-групового скл ду гумусу люві льних лучних т лучно-болотних грунтів з пл ви p. іверський онець х р ктерне перев ж ння гум тів н д фульв т ми. тупінь гуміфік ції орг нічних речовин, здебільшого, середній т високий. скл ді гум тів перев ж ють фр кції, зв'яз ні з льцієм [6].

К 3 зн ч $є$. тк єв, ун слідок інтенсивного сільськогоспод рського використ ння гротемногумусових люві льних грунтів 3 г льн кількість гумусу знизил сь з 3,9 до 3,0\%, співвідношення гк: фк збільшилось головно 3 вдяки зменшенню вмісту фульвокислот, пов'яз них 3 півтор оксид ми. міст негідролізов ного 3 лишку в орних грунт х вищий н $10 \%$, вміст н йв жливішої для утворення грунтової структури фр кщії гумінових кислот, зв'яз них з к льцієм, знизився [11]. йінформ тивнішим пок зником якості гумусу $є$ співвідношення кількості рбону гумінових кислот до кількості рбону в скл ді фульвокислот. ей пок зник відобр ж є зрілість грунту, він м ксим льний $\mathrm{y}$ грунт $\mathrm{x}$ із н йбільшою біологічною ктивністю.

скл ді гумусу люві льних дернових короткопрофільних грунтів з пл ви р. хідний уг перев жє груп фульвокислот ( ), про що свідчить співвідношення гк: фк, яке колив ється в меж х 0,43-0,74 (рис. 1). ип гумусу цих грунтів визн ч ють як гум тно-фульв тний у гумусовому горизонті (співвідношення гк: фк 
ст новить 0,73-0,74) і фульв тний у верхньому піщ ному ш рі грунтотворної породи ( гк: фк - 0,43). йнижчий вміст фульвокислот з фіксов но у верхній ч стині гумусового горизонту (19,9\% від з г льного рбону), униз по профілю він зрост є до $35,3 \%$ у ш рі $1 . \quad$ міст гумінових кислот ( $\quad$ ) поступово зрост є з глибиною.

ерев ж ння фульвокислот н д гуміновими кислот ми в дернових грунт х прируслової ч стини з пл ви . блонських пояснює тим, що в цих грунт х з умов хорошої ер ції т недост тнього вмісту фізичної глини відбув ється швидкий розкл д орг нічних решток і утворення незн чної кількості гумусових кислот. они пог но 3 кріплюються н поверхні піщ них ч сточок, і гумусоутворення розвив ється 3 нех р ктерним для дернових грунтів гум тно-фульв тним типом [12].

жливим пок зником гумусового ст ну грунтів є ступінь гуміфік ції орг нічної речовини, який х р ктеризує ч стку гуміфіков ного м тері лу в скл ді орг нічної речовини т який обчислюють як співвідношення вмісту гумінових кислот до з г льного вмісту всіх орг нічних речовин. тупінь гуміфік ції орг нічної речовини люві льних дернових короткопрофільних грунтів є низьким у меж х усього профілю $14,7-15,8 \%$ (див. т блицю).

p кційно-груповий скл д гумусу люві льних грунтів з пл ви p. хідний уг

\begin{tabular}{|c|c|c|c|c|c|c|c|c|c|c|c|c|c|c|c|c|c|c|}
\hline \multirow[b]{2}{*}{ 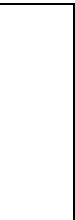 } & \multirow{2}{*}{ 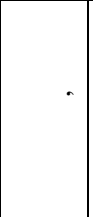 } & \multirow[b]{2}{*}{$\begin{array}{l}\delta^{\circ} \\
\dot{0} \\
\dot{\lambda}\end{array}$} & \multirow[b]{2}{*}{$\begin{array}{c}0 \\
\vdots \\
0\end{array}$} & \multicolumn{4}{|c|}{ умінові кислоти } & \multicolumn{5}{|c|}{ ульвокислоти } & \multirow[b]{2}{*}{ 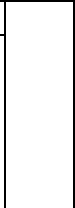 } & \multirow[b]{2}{*}{ 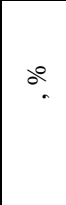 } & \multirow[b]{2}{*}{ 羓 } & \multirow[b]{2}{*}{$\begin{array}{l}\mp \\
\ddot{-}\end{array}$} & \multirow[b]{2}{*}{$\begin{array}{l}\sim \\
\ddot{\sim}\end{array}$} & \multirow[b]{2}{*}{$\begin{array}{l}m \\
\ddot{m}\end{array}$} \\
\hline & & & & 1 & 2 & 3 & $\sum_{\lambda}$ & 1 & 1 & 2 & 3 & $\sum^{\Sigma}$ & & & & & & \\
\hline \multicolumn{19}{|c|}{$\begin{array}{l}\text { люві льний дерновий короткопрофільний к рбон тний глейовий легкосуглинковий грунт н суч сних } \\
\text { люві льних відкл д х, розріз 2- }\end{array}$} \\
\hline \multirow{2}{*}{$\mathrm{HkGl}$} & $1-12$ & 2,50 & 1,45 & 4,3 & 5,8 & 4,6 & 14,7 & 0,9 & 4,0 & 4,6 & 10,4 & 19,9 & 34,4 & 65,4 & 0,74 & 0,9 & 1,3 & 0,4 \\
\hline & $12-23$ & 2,16 & 1,25 & 4,7 & 6,7 & 4,4 & 15,8 & 0,6 & 4,1 & 5,2 & 11,6 & 21,5 & 37,3 & 62,7 & 0,73 & 1,0 & 1,3 & 0,4 \\
\hline${ }_{1} \mathrm{kGl}$ & $24-34$ & 1,01 & 0,59 & 5,1 & 6,8 & 3,4 & 15,3 & 1,6 & 3,4 & 13,3 & 17,0 & 35,3 & 50,6 & 49,4 & 0,43 & 1,0 & 0,5 & 0,2 \\
\hline \multicolumn{19}{|c|}{$\begin{array}{c}\text { люві льний лучний к рбон тний глейовий в жкосуглинковий грунт н суч сних люві льних відкл д х, } \\
\text { розріз 4- }\end{array}$} \\
\hline \multirow{2}{*}{$\mathrm{H}_{1} \mathrm{kGl}$} & $1-11$ & 7,20 & 4,18 & 3,2 & 14,6 & 6,7 & 24,5 & 0,9 & 5,5 & 1,2 & 12,9 & 20,5 & 45,0 & 55,0 & 1,20 & 0,5 & 12,2 & 0,5 \\
\hline & $11-22$ & 3,88 & 2,25 & 1,9 & 15,1 & 6,3 & 23,3 & 0,7 & 3,9 & 2,9 & 8,8 & 16,3 & 39,6 & 60,4 & 1,43 & 0,4 & 5,2 & 0,7 \\
\hline $\mathrm{H}_{2} \mathrm{kGl}$ & $32-42$ & 2,74 & 1,59 & 1,3 & 18,9 & 8,1 & 28,3 & 1,3 & 4,4 & 0,6 & 10,1 & 16,4 & 44,7 & 55,3 & 1,73 & 0,2 & 31,5 & 0,8 \\
\hline \multicolumn{19}{|c|}{$\begin{array}{c}\text { люві льний лучно-болотний к рбон тний середньосуглинковий грунт н суч сних люві льних відкл д х, } \\
\text { розріз 3- }\end{array}$} \\
\hline \multirow{2}{*}{$\mathrm{H}_{1} \mathrm{kGl}$} & $1-12$ & 5,25 & 3,05 & 4,0 & 6,7 & 4,0 & 14,7 & 0,8 & 4,0 & 5,9 & 10,1 & 20,8 & 35,5 & 64,5 & 0,71 & 0,8 & 1,1 & 0,4 \\
\hline & $12-24$ & 4,60 & 2,67 & 3,4 & 7,9 & 4,1 & 15,4 & 0,6 & 3,6 & 7,3 & 7,9 & 19,4 & 34,8 & 65,2 & 0,79 & 0,8 & 1,1 & 0,5 \\
\hline $\mathrm{H}_{2} \mathrm{kGl}$ & $34-44$ & 1,75 & 1,02 & 3,4 & 8,0 & 5,7 & 17,1 & 1,1 & 4,0 & 13,8 & 10,3 & 29,2 & 46,3 & 53,7 & 0,59 & 0,7 & 0,6 & 0,6 \\
\hline PhkGl & $100-110$ & 1,55 & 0,90 & 3,2 & 13,3 & 8,2 & 24,7 & 1,3 & 3,8 & 13,9 & 12,0 & 31,0 & 55,7 & 44,3 & 0,80 & 0,6 & 1,0 & 0,7 \\
\hline $\mathrm{HkGl}$ & $7-24$ & 8,62 & 5,00 & 3,1 & 11,4 & 4,1 & 18,6 & 0,6 & 3,0 & 1,7 & 9,1 & 14,4 & 33,0 & 67,0 & 1,29 & 0,9 & 6,7 & 0,5 \\
\hline IpkGl & 39-49 & 3,47 & 2,01 & 2,0 & 14,3 & 5,6 & 21,9 & 0,5 & 1,5 & 4,6 & 6,2 & 12,8 & 34,7 & 65,3 & 1,71 & 1,0 & 3,1 & 0,9 \\
\hline
\end{tabular}


цих грунт х серед гумінових кислот перев ж є фр кція, зв’яз н 3 льцієм (рис. 2). ї вміст у верхній ч стині гумусового горизонту ст новить 5,8 \% від з г льного рбону (39,8 \% від суми ), що з пок зник ми гумусового ст ну х р ктеризує його як низький. нижній ч стині гумусового горизонту т у верхній ч стині породи ч стк 2 фр кції зрост є до 6,7-6,8 \% (42,4-44,4 \% від суми гумінових кислот), що х р ктеризує її вміст як середній.
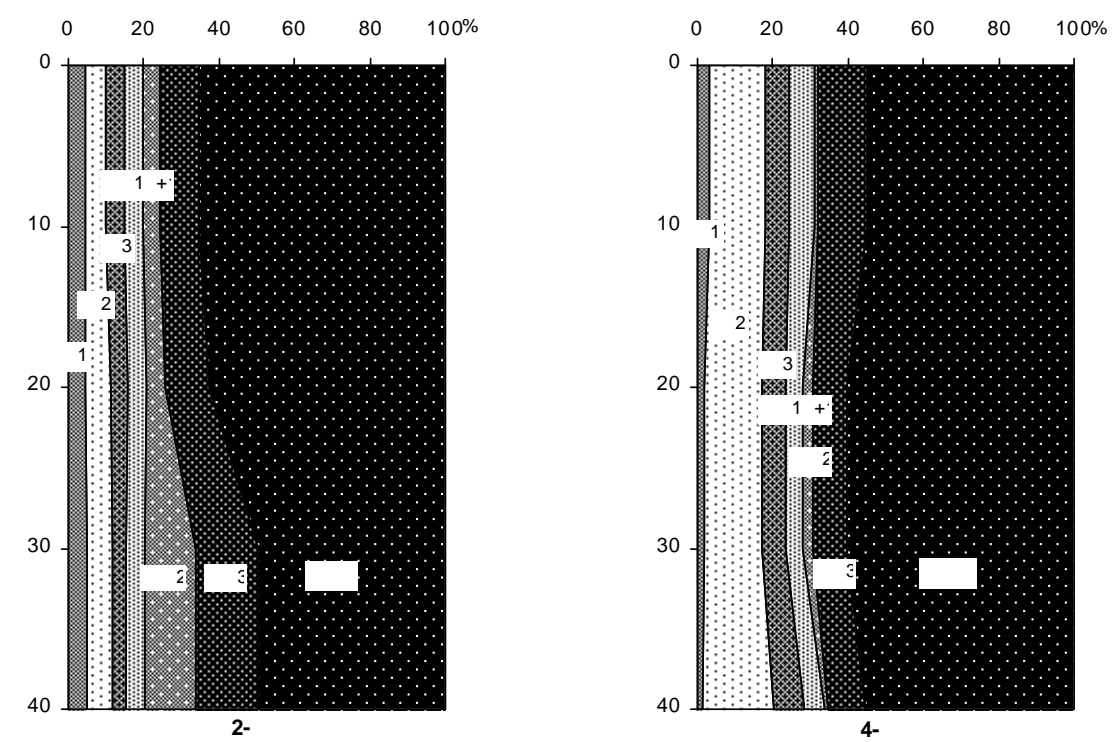

ис. 2. р кційно-груповий скл д гумусу люві льних дернових короткопрофільних (2- ) і лучних (4- ) грунтів з пл ви р. хідний уг.

ля вмісту бурих гумінових кислот (фр кція 1) х р ктерне поступове зрост ння вниз по профілю з 4,3 \% н глибині 1-12 см до 5,1 \% у горизонті 1 (з 29,3 до 33,3 \% від суми ), тобто він є низьким у меж х усього профілю (див. рис. 2).

розподілі по профілю гумінових кислот, міцно зв'яз них з мінер льною ч стиною грунту, виявлено протилежну з кономірність - їхній вміст з глибиною зменшується і колив ється в меж х 3,4-4,6\% (22,2-31,3\% від суми ), що х р ктеризує його як високий.

ерівномірний розподіл по профілю люві льних дернових короткопрофільних грунтів вл стивий і фр кції фульвокислот (див. рис. 2). г лом їхній вміст дещо збільшується з глибиною, що пов'яз но з зн чною кількістю піску, вміст якого вниз по профілю зрост $\epsilon$. н чно перев ж ють фульвокислоти, зв'яз ні з фр кцією

$3(48,2-54,0 \%$ від суми ). ізко зрост є у грунтотворній породі т кож вміст фр кції 2 (з 23,1-24,2 \% від суми в гумусовому горизонті до $37,7 \%$ у верхній ч стині грунтотворної породи).

міст гуміну, який н лежить до ст більних форм гумусу, колив ється у профілі люві льних дернових короткопрофільних грунтів у меж х 49,4-65,4\%. інім льним його вміст є в породі, що збіг ється зі зрост нням вмісту фульвокислот. пок зник ми гумусового ст ну вміст гуміну в ш рі $1 \in$ середнім, в гумусовому горизонті високим (див. т блицю). 
кий зн чний вміст гуміну в досліджув них грунт х можн пояснити тим, що 3 зн чної оглеєності і перезволоження грунту не відбув ється повної тр нсформ ції орг нічних решток рослин, які н дходять у грунт, кумулюється зн чний вміст неповністю гуміфіков них орг нічних речовин, які потр пляють у групу негідролізов ного $з$ лишку. я груп гумусових речовин (нерозчинний з лишок) потенційно може бути джерелом гумінових кислот. д ними досліджень деяких учених [9], до скл ду гумінів поряд з гуміновими речовин ми, які утворюються з гумінової кислоти вн слідок її ст ріння, входять інші, дещо молодші, ніж гумінові кислоти, речовини.

н шу думку, оскільки люві льні грунти є порівняно молодими і перебув ють н ст дії формув ння, то процеси гуміфік ції т формув ння стійких гумусових кислот нез вершені, тому високий вміст гуміну в досліджув них грунт х цілком випр вд ний.

жливе зн чення для оцінки фр кційно-групового скл ду гумусу м ють пок зники співвідношень до у різних фр кціях гумусових речовин (див. т блицю).

люві льних дернових короткопрофільних грунт х простежується м йже одн ковий вміст фр кції 1 гумінових і фульвокислот (співвідношення 1 : $1+1$ ст новить 0,9-1,0). гумусовому горизонті перев ж ють гумінові кислоти, зв'яз ні з льцієм, проте у верхній ч стині піщ ної породи з фіксов но перев ж ння фульвокислот цієї фр кції (співвідношення $\quad 2$ : 2 зменшується від 1,3 до 0,5, відповідно). гумусових речовин різко перев ж ють фульвокислоти. йбільш відмінність між вмістом і простежен в горизонті 1 .

скл ді гумусу люві льних лучних грунтів 3 пл ви р. хідний уг перев ж $є$ груп гумінових кислот, співвідношення гк: фк ст новить 1,20-1,73, що х р ктеризує тип гумусу як фульв тно-гум тний (див. рис. 1). е пов'яз но з дуже високим вмістом фізичної глини в досліджув них грунт х.

тупінь гуміфік ції орг нічної речовини люві льних лучних грунтів є середнім у меж х усього профілю - 23,3-28,3 \% (див. т блицю).

цих грунт х серед гумінових кислот зн чно перев же фр кція, зв'яз н $з$ льцієм (див. рис. 2). ї вміст у верхній ч стині гумусового горизонту ст новить $14,6 \%$ від 3 г льного рбону (59,6\% від суми ), що з пок зник ми гумусового ст ну х р ктеризує його як середній. низ по профілю ч стк фр кції 2 зрост є до 15,1-18,9\% (64,8-66,8 \% від суми гумінових кислот), що х р ктеризує її вміст як високий.

орівняно 3 люві льними дерновими грунт ми в лучних грунт х 3 фіксов но обернену з кономірність у розподілі по профілю вмісту “вільних” і міцнозв'яз них гумінових кислот - у лучних грунт х ч стк фр кції 1 з глибиною зменшується, фр кції 3 - збільшується (див. рис. 2). міст першої фр кції ст новить 1,3-3,2 \% від 3 г льного рбону (4,6-13,1\% від суми ), тобто їі вміст дуже низький, ч стк фр кції 3 ст новить 6,3-8,1\% від 3 г льного рбону (27,0-28,6\% від суми ), що х р ктеризує ï вміст як високий.

йвищий вміст фульвокислот (20,5\% від з г льного рбону) в люві льних лучних грунт х простежено у верхній ч стині гумусового горизонту. низ по профілю їхній вміст зменшується до 16,3-16,4\%. фр кційному скл ді перев ж є фр кція, зв'яз н з фр кцією 3 (54,0-62,9\% від суми ), що пов'яз но зі зн чним вмістом мулу в досліджув них грунт х. Йнижчий вміст мє “гресивн” фр кція 1 4,3-7,9\% від суми . г лом виявлено нерівномірний розподіл по профілю всіх фр кцій фульвокислот.

пок зник ми гумусового ст ну вміст гуміну в профілі люві льних лучних грунтів є середнім і колив ється в меж х 55,0-55,3\% від з г льного рбону. ростежуєть- 
ся деяке його збільшення в нижній ч стині гумусового горизонту (60,4\%), що відповід є високому вмісту (див. т блицю).

люві льних лучних грунт х пок зники співвідношень до $\quad$ у різних фр кціях гумусових речовин є різко диференційов ними. ля цих грунтів х р ктерне вир жене перев ж ння фульвокислот фр кції 1 н д гуміновими кислот ми тієї ж фр кції (співвідношення 1: $1+1$ ст новить $0,2-0,5)$, причому 3 глибиною вон зрост $є$.

люві льних лучних грунт х з фіксов но н йбільше серед усіх досліджув них грунтів домінув ння фр кції 2 гумінових кислот н д фульвокислот ми тієї ж фр кції (співвідношення 2: 2 колив ється в меж х 5,2-31,5), передусім у другому гумусовому горизонті, де гумінові кислоти перев ж ють н д фульвокислот ми в пон д 30 р зів. о всьому профілю перев же фр кція 3 фульвокислот н д гуміновими кислот ми (співвідношення 3: 3 ст новить 0,5-0,8).

скл ді гумусу люві льних лучно-болотних грунтів з пл ви р. хідний уг перев ж є груп фульвокислот, співвідношення гк: фк ст новить 0,59-0,80, що х р ктеризує тип гумусу як гум тно-фульв тний (див. рис. 1). йнижчий вміст фульвокислот виявлено у нижній ч стині гумусового горизонту (19,4\% від з г льного рбону), униз по профілю зрост є до $31,0 \%$ у горизонті PhkGl. міст гумінових кислот поступово зрост є з глибиною.

тупінь гуміфік ції орг нічної речовини досліджув них люві льних лучноболотних грунтів є низьким у гумусових горизонт х $(14,7-17,1 \%)$ i середнім у сл бкогумусов ній породі $(24,7 \%)$.

цих грунт х серед гумінових кислот перев ж є фр кція, зв’яз н 3 льцієм (45,6-53,8 \% від суми ), що 3 пок зник ми гумусового ст ну м є середній вміст (рис. 3).
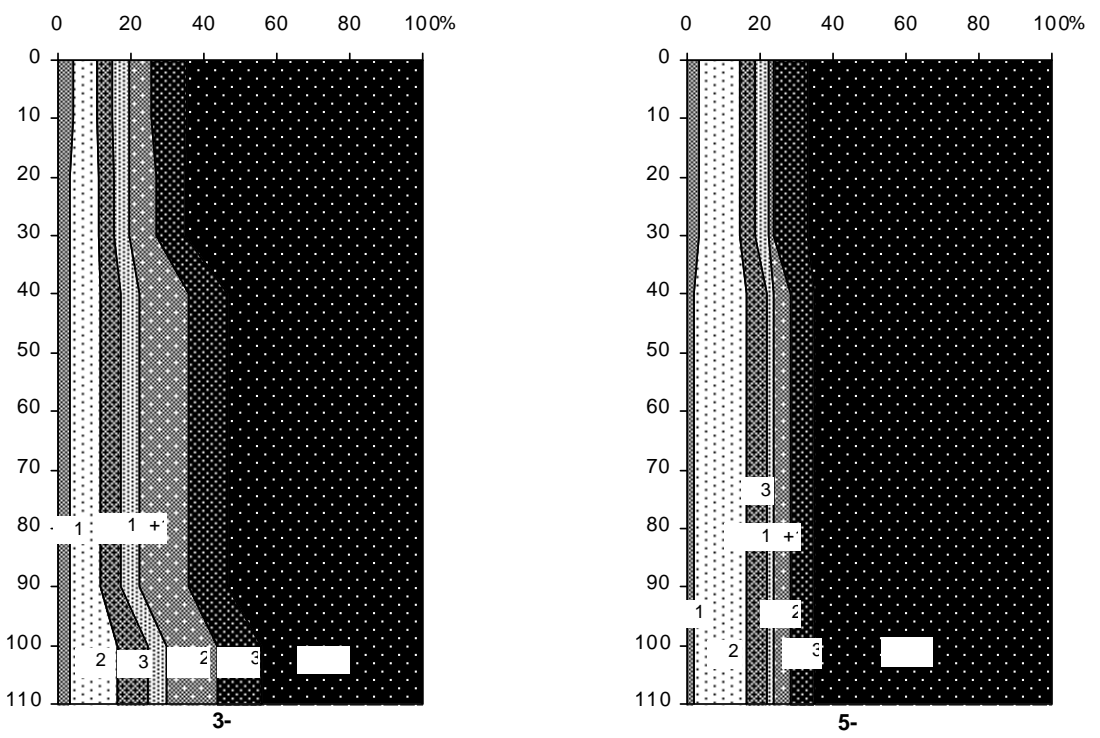

ис. 3. р кційно-груповий скл д гумусу люві льних лучно-болотних (3- ) і болотних (5- ) грунтів з пл ви р. хідний уг. 
розподілі по профілю фр кцій 1 і 3 гумінових кислот простежується н логічн 3 кономірність, як і в люві льних лучних грунт х, - вміст бурих гумінових кислот 3 глибиною зменшується з 4,0 до 3,2\% від з г льного рбону, фр кції, зв'яз ної з мінер льною ч стиною грунту, збільшується з 4,0 до 8,2 \% від 3 г льного рбону (див. рис. 3). міст “вільних” гумінових кислот м є низькі т середні пок зники (13,0-27,2 \% від суми ), фр кції, міцно зв’яз ної з мінер льною ч стиною грунту, високі (26,6-33,3\% від суми ).

еред фульвокислот у верхньому гумусовому горизонті перев ж є фр кція, зв'яз н 3 фр кцією $3\left(40,7-48,6 \%\right.$ від суми ), в горизонті ${ }_{2} \mathrm{kGl}$ т в сл бкогумусов ній породі - фр кція, зв'яз н 3 льцієм (44,4-47,3\% від суми ). уже низький вміст м є “ гресивн” фр кція 1 (0,6-1,3\% від з г льного рбону).

міст гуміну у верхньому гумусовому горизонті люві льних лучно-болотних грунтів ст новить 64,5-65,2\% і є високим. низ по профілю його зн чення зменшуються до 44,3-53,7 \%, що є н йнижчим вмістом гуміну серед усіх досліджув них грунтів.

люві льних лучно-болотних грунт х вміст фр кції $1 €$ дещо вищим у фульвокислот (співвідношення 1: $1+1$ колив ється в меж $\mathrm{x} 0,6-0,8$ ). еодн кове по профілю співвідношення гумінових і фульвокислот, зв'яз них з льцієм. прикл д, у верхньому гумусовому горизонті перев ж ють гумінові кислоти, у горизонті ${ }_{2} \mathrm{kGl}-$ фульвокислоти, в сл бкогумусов ній м теринській породі з реєстров но одн ковий вміст i . піввідношення 3: 3 свідчить про зн чне перев ж ння фульвокислот: $3: \quad 3-0,4-0,7$ (див. т блицю).

скл ді гумусу люві льних болотних грунтів перев ж є груп гумінових кислот. скл ді гумусу люві льних лучних грунтів з пл ви р. хідний уг перев ж є груп гумінових кислот, співвідношення гк: фк ст новить 1,29-1,71, що х р ктеризує тип гумусу як фульв тно-гум тний (див. рис. 1). е пов'яз но 3 дуже високим вмістом фізичної глини в досліджув них грунт х.

тупінь гуміфік ції орг нічної речовини люві льних болотних грунтів є низьким у гумусовому горизонті (18,6 \%) і середнім у перехідному до породи горизонті $(21,9 \%)$.

цих грунт х серед гумінових кислот зн чно перев ж є фр кція, зв'яз н 3 льцієм (див. рис. 3). ї вміст у профілі досліджув них грунтів колив ється в меж х 61,3-65,3\% від суми , що з пок зник ми гумусового ст ну х р ктеризує його як високий.

озподіл по профілю фр кцій 1 т 3 гумінових кислот є н логічним, як і в лучних т лучно-болотних грунт х. міст бурих гумінових зменшується з глибиною від 16,7 до $9,1 \%$ від суми , що є дуже низьким. міст фр кції, зв'яз ної з мінер льною ч стиною грунту, поступово зрост є з глибиною від 22,0 до 25,6\% від суми , що відповід є високим пок зник м їхнього вмісту.

ля групи фульвокислот х р ктерне незн чне зменшення вмісту вниз по профілю з 14,4\% від з г льного рбону в гумусовому горизонті до $12,8 \%$ у перехідному горизонті. верхній ч стині профілю зн чно перев же фр кція $3(63,2 \%$ від суми ), у нижній ч стині їі вміст зменшується до 48,4\%, н томість зрост є ч стк фр кції, зв'яз ної з фр кцією 2 (з 11,8 до 35,9\% від суми ). міст “ гресивної” фр кції 1 є дуже низьким (3,9-4,2\% від суми ).

люві льні болотні грунти м ють н йвищий вміст гуміну серед усіх досліджув них грунтів з пл ви р. хідний уг (65,3-67,0\%), що відповід є високим пок зник м. цих грунт х простежується м йже одн ковий вміст фр кції 1 гумінових і фульвокислот (співвідношення 1: $1+1$ ст новить 0,9-1,0). н чно перев ж ють , зв'яз ні з льцієм ( 2: $2-3,1-6,7)$. фіксов но незн чне перев ж ння фульвоки- 
слот н д гуміновими кислот ми фр кції 3, зв'яз ної з мінер льною ч стиною грунту ( 3: 3-0,5-0.9).

тже, дослідження фр кційно-групового скл ду гумусу люві льних грунтів з пл ви р. хідний уг з свідчили, що вони м ють гум тно-фульв тний ( люві льні дернові короткопрофільні т лучно-болотні грунти) т фульв тно-гум тний ( люві льні лучні т болотні грунти) типи гумусу. еред фр кцій зн чно перев ж ють фр кції, зв'яз ні з льцієм, серед - фр кції, міцно зв'яз ні з мінер льною ч стиною грунту. иявлено дуже низький вміст “гресивних” . р ктерною особливістю люві льних грунтів є високий вміст гуміну.

\section{СПИСОК ВИКОРИСТАНОЇ ЛІТЕРАТУРИ}

1. овк . люві льні н носи річок к рп тської низовини і їх роль у з пл вному грунтоутворенні / кс н овк, лег рлов // енез, геогр фія т екологія грунтів : [збірник н ук. пр ць]. - ьвів, 2008. - . 113-120.

2. рифуллин . . умусное состояние ллюви льных почв p. елой / . . рифуллин, . . оновков // очвы речных долин и дельт, их р цион льное использов ние и охр н : м тери лы сесоюз. конф. - . : зд-во оск. ун-т , 1984. - . 59-60.

3. орін . . пл вне грунтотворення олісся т лісостепу кр їни (еволюція, біогеохімія, окультурюв ння) : втореф. дис. н здобуття н ук. ступеня д-р біол. н ук / . . орін. - ., 2002. -42 с.

4. ришин . . умусное состояние пойменных почв, его оптимиз ция и охр н / . . ришин // очвы речных долин и дельт, их р цион льное использов ние и охр н : [м тери лы сесоюз. конф.]. - . : зд-во оск. ун-т , 1984. - .60-61.

5. обровольский . . очвы речных пойм центр усской р внины / . . обровольский ; 2-е изд., перер б. и доп. - . . з зд-во оск.ун-т , 2005. 293 c.

6. зют . . собливості розвитку т використ ння з пл вних лісових грунтів p. іверський онець у лісостепових умов х : втореф. дис. н здобуття н ук. ступеня к нд. с.-г. н ук : спец. 06.01.03 грогрунтозн вство і грофізик / зют лекс ндр икол йович. - ., 2004.-21 с.

7. конечний . . рунти з пл ви ріки хідний уг : моногр фія / . . конечний, . . озняк. - ьвів : імені в н р нк, 2011.-220 с.

8. рлов . . рг ническое вещество почв оссийской едер ции / . . рлов, . . ирюков , . . ух нов . - . : ук , 1996. -256 с.

9. ридвориев . . негидролизуемом ост тке гумус черноземов / . . ридворцев, . . едов, . . ерзилин, . . оролев // очвоведение. 2006. - № 4. - . 450-457.

10. $л$ внин . . умусное состояние и содерж ние основных элементов пит ния в почв х поймы средней би / . . л внин , . . х ткин , . . ередин // очвы речных долин и дельт, их р цион льное использов ние и охр н : [м тери лы сесоюз. конф.] - . : Зд-во оск. ун-т , 1984. - .77-78.

11. $m \kappa$ ев . . изические свойств грогенноизмененных ллюви льных почв / . . тк ев // овременные проблемы почвоведения. - . : очвенный ин-т им. . . окуч ев , 2000. - .445-456. 
12. блонских . . собенности сост в орг нического веществ ллюви льных болотных почв / . . блонских // естник . ер. химия, биология. - 2001. № 2. - . 178-181.

m ття:н дійшл до ред кцї̈ 20.04.2013

доопр иьов н 06.05 .2013

прийнят до друку 17.06.2013

\title{
GROUP FRACTIONAL COMPOSITION OF HUMUS OF ALLUVIAL SOILS OF FLOODPLAIN OF WESTERN BUG RIVER
}

\author{
Yuriy Nakonechnyy \\ Ivan Franko National University of Lviv, \\ P. Doroshenko St., 41, UA - 79000, Lviv, Ukraine
}

Fractionally-group composition of humus alluvial turf, meadow, meadow marsh and bog soils of floodplain of Western Bug River was characterized. The results of studies of quality of soil humus of floodplain of this river by Ukrainian and foreign researchers were analyzed. The main indicators of fractionally-group composition of humus soils were studied.

Key words: alluvial soils, humus of soil, fractionally-group composition of humus, humic acids, fulvic acids.

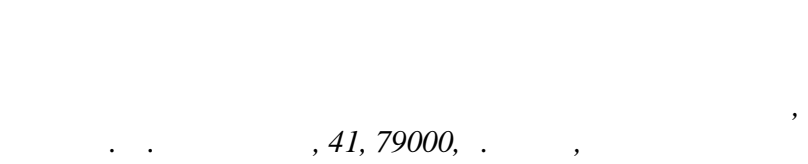

x p ктеризов но фр кционно-групповой сост в гумус ллюви льных дерновых, луговых, лугово-болотных и болотных почв поймы р. п дный уг. ро н лизиров но результ ты исследов ний к чественного сост в гумус почв пойми реки отечественных и 3 рубежных исследов телей. ссмотрено основные пок з тели фр кционно-группового сост в гумус исследуемых почв.

лючевые слов : ллюви льные почвы, гумус почвы, фр кционно-групповой сост в гумус , гуминовые кислоты, фульвокислоты. 